\title{
Neuromyelitis optica
}

BAKGRUNN Neuromyelitis optica (NMO) er en sjelden autoimmun inflammatorisk sykdom i sentralnervesystemet som hovedsakelig kjennetegnes av residiverende optikusnevritt og langstrakt tverrsnittsmyelitt. Formålet med denne artikkelen er å presentere oppdatert kunnskap om kliniske symptomer, diagnostikk, patogenese og behandling av tilstanden.

KUNNSKAPSGRUNNLAG Oversikten er basert på et skjønnsmessig utvalg av engelskspråklige originalartikler, metaanalyser og oversiktsartikler funnet i PubMed og på forfatternes egne erfaringer med pasientgruppen.

RESULTATER Tidligere var neuromyelitis optica antatt å være en variant av multippel sklerose, men oppdagelsen av akvaporin-4-antistoff hos pasienter med neuromyelitis optica har endret kunnskapsgrunnlaget. Årsaken til utvikling av tilstanden er ennå ukjent, men det er vist at antistoffene binder selektivt til en vannkanal hovedsakelig uttrykt på astrocytter ved blod-hjerne-barrieren, som har en viktig rolle i regulering av hjernevolum og ionehomøostase. Klinisk kjennetegnes tilstanden av optikusnevritt og/eller tverrsnittsmyelitt. Diagnosen stilles på grunnlag av anamnese, klinisk undersøkelse, MR-undersøkelse av hjerne og ryggmarg, analyse av cerebrospinalvæske, visuelt fremkalt respons og blodprøve med analyse for akvaporin-4-antistoff. Når diagnosen er stilt, er rask behandling viktig. I akuttfasen anbefales metylprednisolon intravenøst. Til forebygging er det flere alternativer, men primært anbefales peroral behandling med prednisolon og azatioprin eller intravenøs infusjon med rituximab. Behandlingen skiller seg fra den som gis ved multippel sklerose. Noen av de vanlige immunmodulerende medikamentene brukt ved multippel sklerose kan føre til forverring av neuromyelitis optica.

FORTOLKNING Tilstanden er en viktig differensialdiagnose til multippel sklerose, men skiller seg fra denne både klinisk, prognostisk og behandlingsmessig. Pasientene har stor risiko for sekvele etter anfall, og det er derfor viktig med tidlig diagnose og behandling.

Neuromyelitis optica (NMO) er en demyeliniserende sykdom i sentralnervesystemet som er assosiert med antistoffer mot akvaporin-4. Tilstanden er sjelden, men kan forveksles med multippel sklerose og er derfor viktig å kjenne til. Pasienter med neuromyelitis optica debuterer typisk med optikusnevritt eller tverrsnittsmyelitt og kan oppsøke lege med symptomer som sløret syn og smerter ved øyebevegelser, nummenhet under et bestemt tverrsnittsnivå eller lammelser.

\section{Kunnskapsgrunnlag}

Denne oversikten bygger på forfatternes egne kliniske erfaringer med pasientgruppen samt et skjønnsmessig utvalg av engelskspråklige original- og oversiktsartikler funnet etter litteratursøk i PubMed med søkeordene «neuromyelitis optica» og «NMO» kombinert med «history», «symptoms», «aquaporin 4», «NMO-IgG», «MRI», «pathology», «treatment», «prognosis», «multiple sclerosis», «NMO spectrum disorders». Søket ble avsluttet i februar 2013.

\section{Historikk}

Den første som beskrev en sammenheng mellom optikusnevritt og myelitt hos en pasient, var sir Thomas Albutt i 1870 (1).
Betegnelsen neuromyelitis optica ble forste gang brukt i 1894 av den franske nevrologen Eugène Devic, som beskrev 16 pasienter. Beskrivelsen ble utgangspunkt for fastsetting av diagnosekriterier for tilstanden, som deretter også ble kalt Devic's disease. Neuromyelitis optica var i over 100 år antatt å være en variant av multippel sklerose, på tross av observerte ulikheter i pasientgruppene.

I 2004 ble sirkulerende IgG1-antistoff mot akvaporin-4 påvist i serum hos en undergruppe av pasienter med antatt multippel sklerose (2). Dette førte til en ny forståelse av neuromyelitis optica, som nå er etablert som en egen sykdomstilstand.

\section{Forekomst}

Prevalensen er ca. 1/100 000 individer (3). Tilstanden er regnet å være hyppigst i ikkekaukasiske befolkningsgrupper. Andelen pasienter med demyeliniserende sykdom som fyller kriteriene for neuromyelitis optica utgjør bare $1-2 \%$ blant pasienter fra Europa, Nord-Amerika og Australia, men $20-50 \%$ av pasienter i Karibia og Asia (4).

Det er ikke gjort studier på prevalens av neuromyelitis optica i Norge, men i en dansk studie fant man en overraskende høy prevalens på 4,4/100 000 (5). Ratioen kvinner :

\author{
Silje Agnethe Stokke Kvistad \\ silje.agnethe.stokke@helse-bergen.no \\ Stig Wergeland \\ Øivind Torkildsen \\ Nevrologisk avdeling \\ Haukeland universitetssykehus \\ Kjell-Morten Myhr \\ Nevrologisk avdeling \\ Haukeland universitetssykehus \\ og \\ KG Jebsen senter for MS-forskning \\ Klinisk institutt 1 \\ Universitetet i Bergen

\section{Christian A. Vedeler} \\ Nevrologisk avdeling \\ Haukeland universitetssykehus \\ og \\ Klinisk institutt 1 \\ Universitetet i Bergen \\ Se også kunnskapsprøve \\ på www.tidsskriftet.no/quiz
}

\section{HOVEDBUDSKAP}

Neuromyelitis optica er en sjelden inflammatorisk, demyeliniserende lidelse i sentralnervesystemet hvor man har identifisert et spesifikt antistoff rettet mot akvaporin-4 på astrocytter

Tilstanden er en viktig differensialdiagnose til multippel sklerose.

Tidlig diagnose og behandling er viktig for å hindre gjentatte anfall, som kan føre til permanent funksjonssvikt 

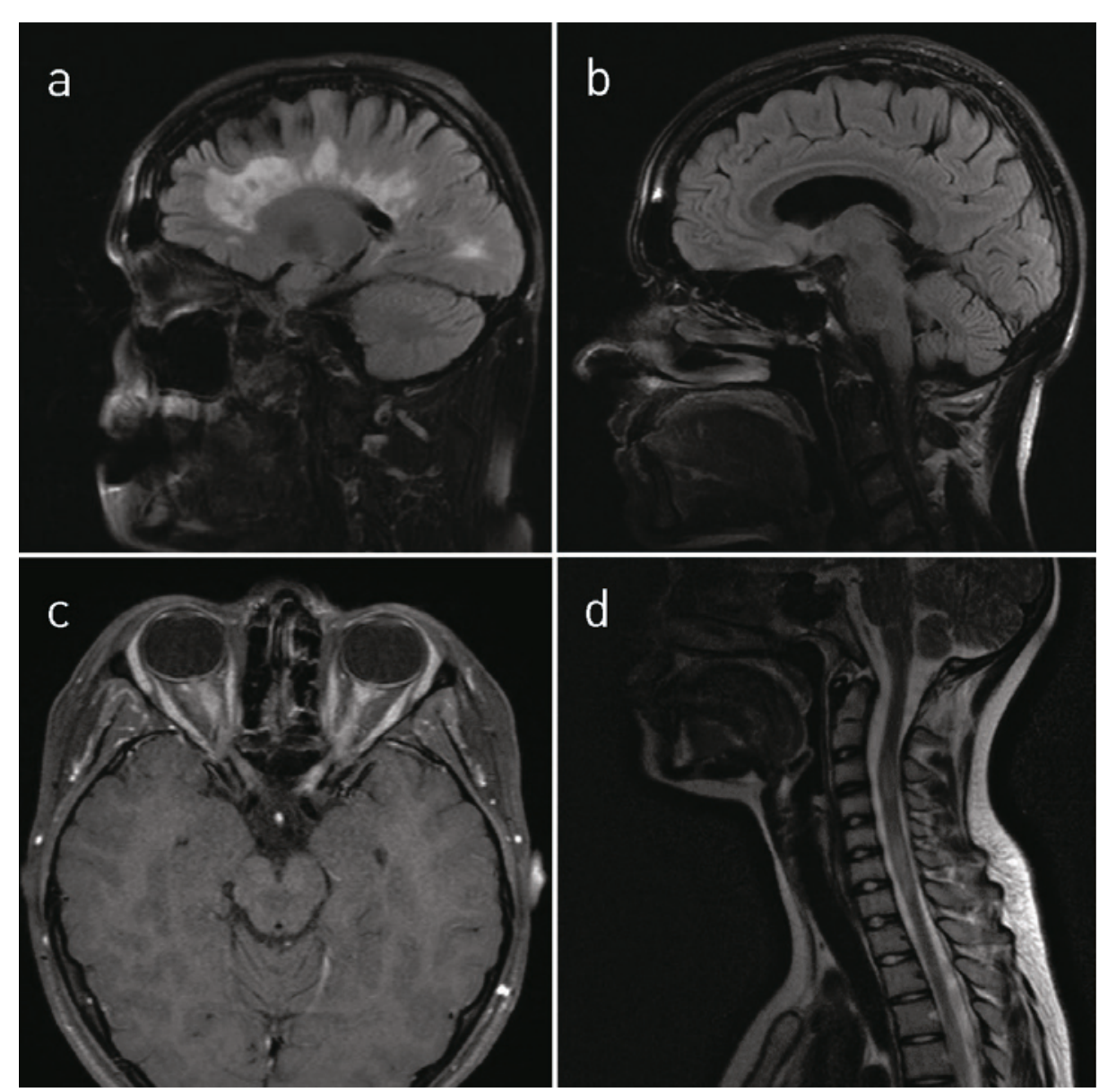

Figur 1 a) MR-bilde som viser typiske periventrikulære forandringer hos pasient med multippel sklerose. b) Dette ses vanligvis ikke hos pasienter med neuromyelitis optica. c) Ved neuromyelitis optica ses ofte optikusnevritt, i dette tilfellet bilateralt, og d) myelitt, i dette tilfellet i cervikal medulla

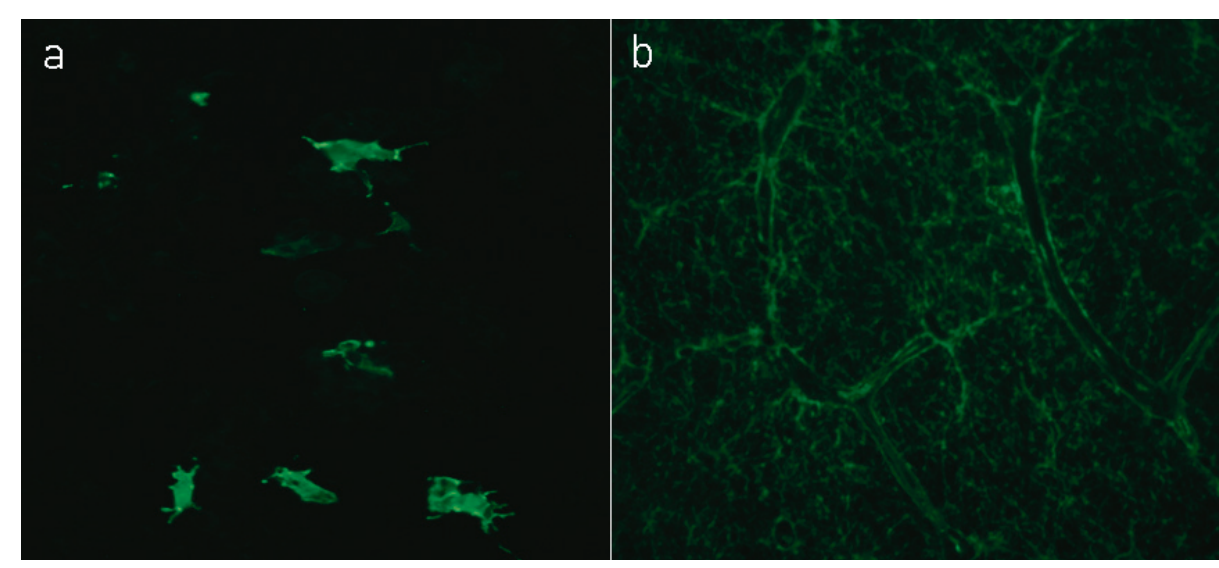

Figur 2 al Antistoff i serum fra pasient med neuromyelitis optica som farger transfekterte akvaporin-4-celler, og b) akvaporin-4 i tverrsnitt av n. opticus

menn er 3-9:1 $(3,6)$. Gjennomsnittlig debutalder er 39 år (7), hvilket er opp mot ti år senere enn for multippel sklerose, men også barn og eldre kan bli rammet (8).

\section{Utredning og kliniske symptomer}

Neuromyelitis optica er klinisk karakterisert av optikusnevritt, som kan være bilateral, og transvers myelitt som strekker seg over mer enn tre vertebralsegmenter. Vanlige symptomer ved optikusnevritt er synstap og retrobulbære smerter som forverres ved øyebevegelser. Pasienter med myelitt kan ha paraeller tetraparese, sensibilitetstap under et bestemt ryggmargsnivå samt blæredysfunksjon. I noen tilfeller kan pasientene få symptomer fra hjernestammen som kvalme, hikke og i alvorlige tilfeller respirasjons- vansker. Det kliniske forløpet kan være monofasisk, men ca. $90 \%$ av pasientene får gjentatte episoder, oftest innen 2-3 år etter sykdomsdebut $(9,10)$.

I tillegg til anamnese og klinisk undersøkelse inkluderer utredningen MR-undersøkelse (magnetisk resonanstomografi) av hjerne og ryggmarg, analyse av cerebrospinalvæske, visuelt fremkalt respons og blodprøver (fig 1). Ved neuromyelitis optica kan det påvises et spesifikt antistoff rettet mot akvaporin-4, en osmosedrevet vannkanal (fig 2). Dette finnes i serum hos ca. $75 \%$ av pasientene $(2,11)$. Antistoffet kan også påvises i cerebrospinalvæsken, men kun forbigående $\mathrm{i}$ akuttfasen hos et fåtall av pasientene. Rutinemessig undersøkes derfor kun serum for slike antistoffer. Ifølge europeiske retningslinjer kan det ved høy klinisk mistanke, men negativ akvaporin-4-antistoffprøve være aktuelt å gjenta testen eller teste i cerebrospinalvæsken (12). I Norge utføres disse testene ved Haukeland universitetssykehus og Oslo universitetssykehus, Ullevål.

I akuttforløpet viser cerebrospinalvæsken ofte pleocytose med $50-100 \cdot 10^{6}$ celler/l, oftest polymorfonuklære, og forhøyet proteinnivå. Oligoklonale bånd forekommer hos under $30 \%$ av pasientene. Cerebrospinalvæskefunnene skiller seg fra funn ved multippel sklerose, hvor det vanligvis er mild pleocytose med mononuklære celler og oligoklonale bånd hos over $95 \%$. På grunn av høy grad av astrocyttskade er det påvist et høyere nivå av nevrofilament (neurofilament heavy chain) og av et gliaspesifikt strukturprotein (glial fibrillary acidic protein) i cerebrospinalvæsken hos pasientene med neuromyelitis optica enn hos pasienter med multippel sklerose. Disse prøvene kan muligens bli aktuelle som diagnostiske markører for akvaporin-4-antistoffnegative pasienter (12-14).

Typiske MR-funn hos pasientene er sentrale lesjoner i ryggmargen som strekker seg over minst tre vertebralnivåer. Det er vanlig med normal MR-undersøkelse av hjerne ved debuttidspunktet, men opptil $80 \%$ av pasientene kan etter hvert utvikle cerebrale MR-forandringer. Disse er ofte ukarakteristiske og asymptomatiske $(12,13)$. Bare ca. $10 \%$ har cerebrale MR-funn som regnes som mer typiske for neuromyelitis optica på grunn av lokalisering til områder med høy tetthet av akvaporin-4, som hypothalamus og periakveduktale hjernestammeområder (15-18). Til sammenlikning viser MRundersøkelse av pasienter med multippel sklerose ofte typiske periventrikulære hvitsubstanslesjoner i hjernen samt korte, flekkevise perifere lesjoner i ryggmargen.

Visuelt fremkalt respons måler ledningshastigheten i n. opticus. Hvis pasienten har hatt optikusnevritt vil det ofte manifestere 
Tabell 1 Demografiske og kliniske kjennetegn, utredning, patologiske funn og behandling ved neuromyelitis optica og multippel sklerose

Demografiske kjennetegn

$\begin{array}{lll}\text { Kvinner : menn } & 3-9: 1 & 2-3: 1 \\ \text { Debutalder lår) } & 40-60 & 20-40 \\ \text { Annen autoimmun sykdom } & \text { Vanlig } & \text { Sjelden }\end{array}$

\section{Kliniske tegn}

Cerebrale symptomer

Episoder med optikusnevritt og/eller myelitt

Restsymptomer

Forløp

Utredning

MR hjerne

MR ryggmarg

Cerebrospinalvæske, oligoklonale bånd

Cerebrospinalvæske, celler

Akvaporinantistoff

\section{Patologiske funn}

Tidlige funn

$$
\text { Astrocyttskade, tap av akvaporin-4 før }
$$
demyelinisering

Normal eller uspesifikke funn. Ca.10\% har «typiske» neuromyelitis optica-lesjoner

Langstrakte sentrale lesjoner over 3 vertebrae

$15-30 \%$

Moderat pleocytose, polymorfonukleære celler

Påvises i serum og ev. i cerebrospinalvæske
Vanlig, tidlig i forløpet

Oftest milde

Senere i forløpet

Anfallsvis, etter hvert progredierende hos de fleste

\section{Behandling}

Forebyggende behandling

Prednisolon/azatioprin eller rituximab er førstelinjebehandling
Periventrikulære lesjoner i hvit substans

Perifere asymmetriske lesjoner

$90-95 \%$

Mild pleocytose, mononukleære celler

Påvises ikke seg med redusert ledningshastighet ved visuelt fremkalt respons. Dette kan ses hos både pasienter med neuromyelitis optica og hos pasienter med multippel sklerose.

\section{Diagnosekriterier}

Ifølge Wingerchuk og medarbeideres diagnosekriterier fra 2006 skal pasienter med neuromyelitis optica ha optikusnevritt og myelitt samt minst to av tre av følgende tilleggskriterier $(12,19)$ :

- Medullær(e) MR-lesjon(er) som strekker seg over minst tre vertebrae

- Ikke typiske multippel sklerose-funn på MR-undersøkelse (normal cerebral MR eller atypiske lesjoner)

- Akvaporin-4-antistoff i serum

Kriteriene har en spesifisitet på 83,3\% og en sensitivitet på 87,5\% (20). Merk at det ikke er krav om sammenfall i tid for optikusnev- ritt og myelitt. Et internasjonalt panel av eksperter på multippel sklerose kom i 2008 med et forslag til reviderte kriterier for neuromyelitis optica, hvor det legges mer vekt på funn ved MR-undersøkelse. I tillegg ble utelukkelse av autoimmune sykdommer inkludert som et eget hovedkriterium (21).

Det er utarbeidet europeiske retningslinjer for diagnostikk av neuromyelitis optica hvor både kriteriene fra 2006 og 2008 vektlegges, men det er ikke tatt stilling til hvilke av kriteriene som er best egnet for å sette diagnosen (12).

\section{Varianter av neuromyelitis optica}

Pasienter med akvaporin-4-antistoff i serum som ikke fyller diagnosekriteriene, hører til i gruppen som på engelsk kalles «NMO spectrum disorders». Dette gjelder pasienter med gjentakende isolert transvers myelitt eller optikusnevritt, pasienter med transvers myelitt eller optikusnevritt assosiert med autoimmune sykdommer og pasienter med hjernelesjoner typiske for neuromyelitis optica. $10-40 \%$ av pasienter med neuromyelitis optica har komorbide autoimmune tilstander som eksempelvis systemisk lupus erythematosus, Sjögrens syndrom, hypotyreose og myasthenia gravis $(9,16,22)$.

\section{Differensialdiagnostikk}

Flere tilstander kan gi symptomer som ved neuromyelitis optica. Initialt vil både multippel sklerose, cerebrovaskulær sykdom, malignitet, infeksjoner i sentralnervesystemet, metabolske forstyrrelser, arvelige optikusnevropatier og andre øyesykdommer i retina, akutt disseminert encefalomyelitt og Guillain-Barrés syndrom kunne være aktuelle differensialdiagnoser (12). Grundig anamnese med vektlegging av tilleggssymptomer og utredning med blodprøver, MR- 
undersøkelser og spinalpunksjon vil oftest være avklarende.

Å skille neuromyelitis optica fra multippel sklerose kan derimot være en diagnostisk utfordring. Begge tilstandene kan debutere med myelitt og optikusnevritt. Utredning med MR-undersøkelse og spinalpunksjon kan i noen tilfeller vise funn mer forenlig med én av tilstandene og slik være oppklarende. Hos pasienter hvor det etter grundig anamnese og utredning ikke er klassiske multippel sklerose-funn som gjør diagnosen sikker, anbefales utredning med serumakvaporin-4-antistoffmåling.

Ved mistenkt neuromyelitis optica er den diagnostiske sensitiviteten $54-91 \%$ og spesifisiteten over $90 \%$ for akvaporin-4-antistoff $(23,24)$. Det er viktig å kunne skille tilstandene klart fra hverandre, da det er ulik prognose og forskjellig behandlingsregime. Pasienter med neuromyelitis optica har ofte alvorligere symptombilde og dårligere remisjon etter forverringsepisoder enn pasienter med multippel sklerose, dermed også større sekveler og akkumulerende funksjonssvikt $(3,25)$. I tabell 1 presenteres de viktigste forskjellene mellom neuromyelitis optica og multippel sklerose $(8,18,23,26)$.

\section{Patologi og patofysiologi}

Det finnes genetisk predisponerende faktorer for neuromyelitis optica - ca. 3\% har affiserte slektninger (6) og visse HLA-vevstyper er assosiert med tilstanden $(4,6,27)$.

Akvaporin-4-antistoffet, som er påvist ved tilstanden, binder selektivt til denne vannkanalen, som hovedsakelig er uttrykt $i$ astrocyttenes fotprosesser ved blod-hjerne-barrieren. I sentralnervesystemet finnes akvaporin-4 hovedsakelig i retina, n. opticus, hypothalamus, cerebellum, periventrikulære og periakveduktale regioner og i medulla (6).

Akvaporin-4 har en viktig rolle når det gjelder væskebalansen mellom hjerneceller, blod og cerebrospinalvæske og er dermed et viktig element i reguleringen av hjernevolum og ionehomøostase $(28-30)$. Den utløsende mekanismen for utvikling av autoimmunitet er ukjent. I de fleste tilfeller foreligger det ingen utløsende hendelse, men det er beskrevet tilfeller med forutgående infeksjoner. Også forutgående vaksinasjon og kreft, særlig lungekreft, brystkreft og lymfom, har vært foreslått som mulige triggermekanismer $(6,9,16,17)$. Akvaporin-4-antistoffene bidrar sannsynlig i patogenesen, men det er ikke kartlagt hvordan disse passerer blod-hjerne-barrieren.

Typiske nevropatologiske funn ved neuromyelitis optica er demyelinisering, aksontap og nekrose i hvit og grå substans. Tidlige patologiske funn er karakterisert av akutt skade av perivaskulære astrocytter og uttalt tap av akvaporin-4 med påfølgende demyelinise- ring. Dette skiller seg fra patologiske funn ved multippel sklerose, hvor tap av oligodendrocytter og myelinfragmentering er de tidligste funn $(13,18)$.

\section{Behandling}

Pasienter med neuromyelitis optica har stor risiko for sekvele etter anfall - rask diagnose og behandling er derfor viktig. I retningslinjene fra European Federation of Neurological Societies (EFNS) anbefales høydose intravenøs metylprednisolon i 3-5 dager som akuttbehandling (12). Studier har vist at ca. $80 \%$ av pasientene responderer på dette (9). Ved manglende respons etter fem dagers behandling eller ved kun delvis respons i løpet av 7-10 dager anbefales plasmaferese (12, 31-33). Immunglobuliner intravenøst har også vært forsøkt som behandling, men det foreligger ingen større studier på dette.

Forebyggende behandling bør startes straks diagnosen er stilt for å hindre nye anfall. Anbefalt førstelinjebehandling ifølge europeiske retningslinjer er prednisolon og azatioprin peroralt eller intravenøs infusjon med rituximab (12). Vanlig dosering av azatioprin er $2,5-3 \mathrm{mg} / \mathrm{kg} / \mathrm{dag}$. Det er vanlig å gi preparatet i kombinasjon med prednisolon de første tre månedene, da man ikke oppnår optimal effekt før dette. Prednisolon gis vanligvis i dosen $60 \mathrm{mg}$ daglig de første ukene, deretter er det gradvis nedtrapping over tre måneder til seponering. Rituximabdoseringen er $1 \mathrm{~g}$ intravenøst dag $1 \mathrm{og}$ dag 14, som kan gjentas hver 6.-9. måned. Ved en del behandlingssentre styres dette av når CD19-kvantitering av B-celler begynner å stige. I flere studier er signifikant forebyggende effekt av behandling med azatioprin og rituximab bekreftet $(7,15,34-37)$.

For dem som ikke responderer på førstelinjebehandling, vil mykofenolamofetil i opptrappende dosering til $1 \mathrm{~g} \times 2$ være et godt alternativ $(33,38,39)$. Annen potensielt effektiv behandling er metotreksat 15-25 mg per uke sammen med folat (33). Flere behandlingsalternativer er under utprøvning, og særlig et nytt komplementhemmende antistoff kalt eculizumab har vist lovende resultater (40). Sannsynlig trengs det behandling med immunsuppressiv medikasjon over år. Hvis pasienten har vært anfallsfri i flere år og ikke lenger har påvisbare akvaporin-4-antistoffer, kan man forsøksvis gradvis seponere den immunsuppressive behandlingen.

Alle pasienter med neuromyelitis opticavariant skal ha akuttbehandling med metylprednisolon og eventuelt plasmaferese ved manglende effekt. Ofte anbefales tidlig oppstart av forebyggende behandling hos slike pasienter med alvorlige utfall og/eller akvaporin-4-antistoff i serum. Ved kun milde utfall og manglende antistoff vil man ofte avvente forebyggende behandling, som imidlertid må vurderes hvis det kommer nye symptomer (12).

Pasienter med neuromyelitis optica kan utvikle kroniske plagsomme symptomer som smerter, spastisitet og blæredysfunksjon, og symptomatisk behandling er derfor viktig.

Det er viktig å skille neuromyelitis optica fra multippel sklerose, da medikamentene som brukes mot multippel sklerose, som betainterferon, natalizumab og fingolimod, kan føre til forverring av neuromyelitis optica (15, 18, 41-44). Hvorvidt glatirameracetat også kan brukes ved neuromyelitis optica, er usikkert (45).

\section{Prognose}

Gjentatte episoder med myelitt eller optikusnevritt med akkumulerende funksjonssvikt ses hos $90 \%$ av pasientene.

Faktorer som taler for residiverende forløp er kvinnekjønn, høy debutalder og komorbiditet med annen autoimmun sykdom $(3,9)$. Det er typisk at symptombildet forverres over dager for så å bli bedre i løpet av uker og måneder, men pasientene får vanligvis restsymptomer. Det er mer uttalte kliniske symptomer ved neuromyelitis optica enn ved multippel sklerose, men dette kan variere. Pasienter som har akvaporin-4-antistoff har ofte verre anfall (11). Hyppige tilbakefall de første to år av sykdommen, alvorlig første episode og komorbiditet med annen autoimmun sykdom taler for dårlig prognose $(10,46)$. Som ved multippel sklerose er det også ved neuromyelitis optica økt risiko for anfall post partum. Tilstanden går vanligvis ikke over $i$ et sekundært, progredierende forløp, slik man ofte ser ved multippel sklerose.

\section{Konklusjon}

Neuromyelitis optica er en sjelden, men alvorlig demyeliniserende sykdom. Multippel sklerose er den viktigste differensialdiagnosen. Ved begrenset sykdom og ved første episode med kliniske symptomer (klinisk isolert syndrom) kan det være vanskelig å skille mellom neuromyelitis optica og multippel sklerose. En liten andel av seronegative pasienter med neuromyelitis optica vil på et tidspunkt fylle diagnosekriteriene for multippel sklerose - og motsatt. Ca. 7\% av pasienter med klinisk isolert syndrom vil på et tidspunkt fylle diagnosekriteriene for neuromyelitis optica. Det foreligger således en overlapping mellom tilstandene.

Etter oppdagelsen av akvaporin-4-antistoff er tilstanden blitt bedre kartlagt og diagnosekriteriene revidert. Det er sannsynlig at pasienter med neuromyelitis optica diagnostisert før dette hadde en feilaktig multippel sklerose-diagnose. Det er viktig å 
kjenne til sykdommen og stille riktig diagnose tidlig, da tilstanden skiller seg fra multippel sklerose når det gjelder både behandling og prognose (18).

\section{Silje Agnethe Stokke Kvistad (f. 1980)}

er lege i spesialisering

Forfatter har fylt ut ICMJE-skjemaet og oppgir følgende interessekonflikter: Hun har mottatt stipend og reisestøtte fra Biogen Idec.

\section{Stig Wergeland (f. 1978)}

er ph.d. og lege i spesialisering.

Forfatter har fylt ut ICMJE-skjemaet og oppgir følgende interessekonflikter: Han har mottatt forelesningshonorar fra Sanofi-Aventis, reisestøtte fra Novartis, Merck-Serono, Bayer og Biogen Idec og forskningsstøtte fra Biogen Idec.

\section{Øivind Torkildsen (f. 1979)}

er ph.d., postdoktor og lege i spesialisering. Forfatter har fylt ut ICMJE-skjemaet og oppgir følgende interessekonflikter: Han har mottatt forelesningshonorar, reisestøtte, forskningsstøtte og/eller deltatt i legemiddelutprøvning finansiert av Biogen Idec, Genzyme, Novartis, Merck-Serono, Sanofi-Aventis og/eller Teva.

\section{Kjell-Morten Myhr (f. 1963)}

er professor og overlege.

Forfatter har fylt ut ICMJE-skjemaet og oppgir følgende interessekonflikter: Han har mottatt forelesningshonorar, reisestøtte, forskningsstøtte og/eller deltatt i legemiddelutprøvning finansiert av Allergan, Almirall, Bayer-Schering, Biogen Idec, Genzyme, Novartis, Merck-Serono Roche, Sanofi-Aventis og/eller Teva.

\section{Christian Alexander Vedeler (f. 1958)}

er professor og overlege.

Forfatter har fylt ut ICMJE-skjemaet og oppgir følgende interessekonflikter: Han har mottatt reisestipend fra Baxter.

\section{Litteratur}

1. Jarius S, Wildemann B. The history of neuromyelitis optica. J Neuroinflammation 2013; 10: 8 .

2. Lennon VA, Wingerchuk DM, Kryzer TJ et al. A serum autoantibody marker of neuromyelitis optica: distinction from multiple sclerosis. Lancet 2004: 364: 2106-12

3. Kim W, Kim SH, Kim HJ. New insights into neuromyelitis optica. J Clin Neurol 2011; 7: 115-27.

4. Papadopoulos MC, Verkman AS. Aquaporin 4 and neuromyelitis optica. Lancet Neurol 2012; 11: $535-44$.
5. Asgari N, Lillevang ST, Skejoe HP et al. A population-based study of neuromyelitis optica in Caucasians. Neurology 2011: 76: 1589-95.

6. Bukhari W, Barnett MH, Prain K et al. Molecular pathogenesis of neuromyelitis optica. Int J Mol Sc 2012; 13: 12970-93.

7. Oh J. Levy M. Neuromyelitis optica: an antibodymediated disorder of the central nervous system. Neurol Res Int 2012. E-publisert 29.1.2012.

8. Wingerchuk DM, Lennon VA, Lucchinetti CF et al. The spectrum of neuromyelitis optica. Lancet Neurol 2007: 6: 805-15.

9. Wingerchuk DM, Hogancamp WF, O'Brien PC et al. The clinical course of neuromyelitis optica (Devic's syndromel. Neurology 1999; 53: 1107-14.

10. Ghezzi A, Bergamaschi R, Martinelli V et al. Clinical characteristics, course and prognosis of relapsing Devic's Neuromyelitis Optica. J Neurol 2004; 251: 47-52

11. Jarius S, Ruprecht K, Wildemann B et al. Contrasting disease patterns in seropositive and seronegative neuromyelitis optica: A multicentre study of 175 patients. J Neuroinflammation 2012; 9: 14.

12. Sellner J, Boggild M, Clanet $M$ et al. EFNS guidelines on diagnosis and management of neuromyeitis optica. Eur J Neurol 2010: 17: 1019-32.

13. Takano R, Misu T, Takahashi T et al. Astrocytic damage is far more severe than demyelination in NMO: a clinical CSF biomarker study. Neurology 2010; 75: 208-16.

14. Miyazawa I, Nakashima I, Petzold A et al. High CSF neurofilament heavy chain levels in neuromyelitis optica. Neurology 2007; 68: 865-7.

15. Jacob A, McKeon A, Nakashima I et al. Current concept of neuromyelitis optica (NMO) and NMO spectrum disorders. J Neurol Neurosurg Psychiatry 2013; 84: $922-30$

16. Pittock SJ, Lennon VA, Krecke K et al. Brain abnormalities in neuromyelitis optica. Arch Neurol 2006: 63: $390-6$

17. Hinson SR, McKeon A, Lennon VA. Neurological autoimmunity targeting aquaporin-4. Neuroscience 2010; 168: 1009-18.

18. Barnett MH, Sutton I. Neuromyelitis optica: not a multiple sclerosis variant. Curr Opin Neurol 2012; 25: 215-20.

19. Wingerchuk DM, Lennon VA, Pittock SJ et al. Revised diagnostic criteria for neuromyelitis optica. Neurology 2006; 66: $1485-9$

20. Wingerchuk DM. Neuromyelitis optica. Int MS J 2006; 13: 42-50.

21. Miller DH, Weinshenker BG, Filippi M et al. Differential diagnosis of suspected multiple sclerosis: a consensus approach. Mult Scler 2008; 14 1157-74.

22. O'Riordan JI, Gallagher HL, Thompson AJ et al. Clinical, CSF, and MRI findings in Devic's neuromyelitis optica. J Neurol Neurosurg Psychiatry $1996 ; 60: 382-7$

23. Lycke J, Malmeström C. Neuromyelitis optica viktig differentialdiagnos till MS. Tidigt insatt behandling avgörande for prognosen. Läkartidningen 2010: 107: 3212-5.

24. Waters P, Vincent A. Detection of anti-aquaporin-4 antibodies in neuromyelitis optica: current status of the assays. Int MS J 2008; 15: 99-105.

25. Thornton IL, Rizzo JF, Cestari DM. Neuromyelitis optica: a review. Semin Ophthalmol 2011; 26: 337-41.

26. Nevro-Nel. Norsk nevrologisk forenings prosedyrer. http://nevro.legehandboka.no/ (23.7.2013)

27. Matiello M, Kim HJ Kim W et al. Familial neuromyelitis optica. Neurology 2010; 75: 310-5.
28. Lucchinetti CF, Mandler RN, McGavern D et al. A role for humoral mechanisms in the pathogenesis of Devic's neuromyelitis optica. Brain 2002: 125: $1450-61$

29. Nagelhus EA, Mathiisen TM, Ottersen OP. Aquaporin-4 in the central nervous system: cellular and subcellular distribution and coexpression with KIR4.1. Neuroscience 2004; 129: 905-13.

30. Hinson SR, Pittock SJ, Lucchinetti CF et al. Pathogenic potential of $\mathrm{IgG}$ binding to water channel extracellular domain in neuromyelitis optica. Neurology 2007; 69: 2221-31.

31. Llufriu S, Castillo J, Blanco Y et al. Plasma exchange for acute attacks of CNS demyelination: Predictors of improvement at 6 months. Neurology 2009: 73: 949-53.

32. Watanabe S, Nakashima I, Misu T et al. Therapeutic efficacy of plasma exchange in NMO-IgG-positive patients with neuromyelitis optica. Mult Scler 2007; 13: 128-32.

33. Palace J, Leite MI, Jacob A. A practical guide to the treatment of neuromyelitis optica. Pract Neurol 2012; 12: 209-14

34. Mandler RN, Ahmed W, Dencoff JE. Devic's neuromyelitis optica: a prospective study of seven patients treated with prednisone and azathioprine. Neurology 1998; 51: 1219-20.

35. Bichuetti DB, Lobato de Oliveira EM, Oliveira DM e al. Neuromyelitis optica treatment: analysis of 36 patients. Arch Neurol 2010; 67: 1131-6.

36. Bedi GS, Brown AD, Delgado SR et al. Impact of rituximab on relapse rate and disability in neuromyelitis optica. Mult Scler 2011; 17: 1225-30.

37. Pellkofer HL, Krumbholz M, Berthele A et al. Long-term follow-up of patients with neuromyelitis optica after repeated therapy with rituximab. Neurology 2011; 76: 1310-5

38. Carroll WM, Fujihara K. Neuromyelitis optica. Curr Treat Options Neurol 2010; 12: 244-55.

39. Sato D, Callegaro D, Lana-Peixoto MA et al. Treatment of neuromyelitis optica: an evidence based review. Arq Neuropsiquiatr 2012; 70: 59-66.

40. Pittock SJ, Lennon VA, McKeon A et al. Eculizumab in AQP4-lgG-positive relapsing neuromyelitis optica spectrum disorders: an open-label pilot study. Lancet Neurol 2013; 12: 554-62.

41. Papeix C, Vidal JS, de Seze J et al. Immunosuppres sive therapy is more effective than interferon in neuromyelitis optica. Mult Scler 2007: 13: 256-9.

42. Barnett MH, Prineas JW, Buckland ME et al. Massive astrocyte destruction in neuromyelitis optica despite natalizumab therapy. Mult Scler 2012; 18 108-12.

43. Min JH, Kim BJ, Lee KH. Development of extensive brain lesions following fingolimod (FTY720) treatment in a patient with neuromyelitis optica spectrum disorder. Mult Scler 2012; 18: 113-5.

44. Kleiter I, Hellwig K, Berthele A et al. Failure of natalizumab to prevent relapses in neuromyelitis optica. Arch Neurol 2012; 69: 239-45.

45. Wang KC, Lee CL, Chen SY et al. Glatiramer acetate could be a hypothetical therapeutic agent for neuromyelitis optica. Med Hypotheses 2011; $76: 820-2$

46. Wingerchuk DM, Weinshenker BG. Neuromyelitis optica: clinical predictors of a relapsing course and survival. Neurology 2003; 60: 848-53.

Mottatt 29.4. 2013, første revisjon innsendt 21.6. 2013, godkjent 23.7. 2013. Redaktør Sigurd Høye. 